\title{
Effect of Crop Regulation and Fertigation on Quality Characters of Guava (Psidium guajava) CV. Sardar
}

\author{
A. Mahadevan ${ }^{1 *}$, S. Kumar ${ }^{1}$, V. Swaminathan ${ }^{1}$, A. Gurusamy ${ }^{2}$ and T. Sivakumar ${ }^{3}$ \\ ${ }^{1}$ Department of Horticulture, ${ }^{2}$ Department of Agronomy, ${ }^{3}$ Department of Crop Physiology, \\ Agricultural College and Research Institute, Madurai, Tamil Nadu, India 625104 \\ *Corresponding author
}

\section{A B S T R A C T}

\begin{tabular}{|l|}
\hline K e y w o r d s \\
Guava, Quality \\
Characters, Pruning, \\
Fertigation.
\end{tabular}

Keywords

Guava, Quality

Characters, Pruning,

10 November 2017
The investigation entitled "Effect of crop regulation and fertigation on quality charaters of guava (Psidium guajava) cv. Sardar" was carried out at Department of Horticulture, Agricultural College and Research Institute, Madurai, Tamil Nadu during the year 2012-2014. The experiment was laid out in factorial randomized black design. In this experiments three pruning levels $\left(\mathrm{P}_{0}\right.$ without pruning, $\mathrm{P}_{1}-15 \mathrm{~cm}$ pruning, $\mathrm{P}_{2}-30 \mathrm{~cm}$ pruning $)$ and five fertigations $\left(\mathrm{F}_{0}-\right.$ Soil application, $\mathrm{F}_{1}-125 \%, \mathrm{~F}_{2}-100 \%, \mathrm{~F}_{3}-75 \%, \mathrm{~F}_{4}-$ $50 \%$ ) with three replication. The maximum quality was recorded in the treatment $\mathrm{P}_{2}$ and $125 \%$ in guava.

\section{Introduction}

Guava (Psidium guajava L), is one of most popular fruits grown in tropical, sub-tropical and some parts of aired region of India, which belongs to the family of myrtaceae. This fruits originated tropical America and seems to have been from Mexico to Peru. It is fifth most important fruits in area after mango, banana and citrus and apple and fifth most important fruit in production after banana, mango, citrus and papaya. Nature has endowed it liberally to tolerate the drought and flooding condition and adoptability to a wide range of soil and climatic condition.

Its cultural requirement is also very limited. Besides other factor of fruits crop production, nutrients play on the important role in the production of guava. Medeiros (2004) also reported that, the application of NPK fertilizer though the fertigation provided an increment in the diameter of the guava fruits. The total soluble solids, ascorbic acid, reducing sugars, non-reducing sugars, total sugars and pectin content as well as TSS: acid ratio in fruits linearly increased with increasing rates of NPK fertilizer (Lal and Sen, 2001).

The result of study has indicated that whenever pruning has been attempted in guava, there has been a vast improvement in yield and fruit quality, especially, with light pruning (Bajpai et al., 1973). On the other hand Jadhao et al., (1988) reported that severe pruning $(60 \mathrm{~cm}$ from the tip) resulted in the 
most vigorous vegetative growth and the highest fruit yield and quality in guava. Drip irrigation proved efficiently in providing irrigation water and nutrients to the roots of plant, while maintaining high yield and quality production.

Many researchers have reported the higher application efficiency of drip irrigation systems over the conventional basin irrigation systems (Salvin et al., 2000; Bharambe et al., 2001; Agrawal and Agrawal, 2007) compared to drip and basin irrigation systems in fruits and found that there was savings of 40 to $60 \%$ more irrigation water than basin irrigation methods.

Kumar et al., (2007) reported fertigation ensures substantial saving in fertilizer usage and reduces leaching losses. Sharma et al., (2011) observed higher guava yield and quality through fertigation than basin irrigation. To best of our knowledge no study has reported the combined effect of pruning and fertigation. Hence, the present study was formulated to study the combined effect of pruning and fertigation in guava.

\section{Materials and Methods}

\section{Experimental site and treatment details}

The experimental was conducted at Department of Horticulture, Agricultural College and Research Institute, Madurai, Tamil Nadu, the experiment was laid out in factorial randomized block design (FRBD) with three replications during the year 2012 to 2013 and 2013 to 2014, on uniform 10-yearsold 'Sardar' guava plants planted at the spacing of $6 \times 6 \mathrm{~m}$. The research experiment conducted in the Farmers Field at Dhavathanapatti village, Theni District, Tamil Nadu. The study aimed to standardize the pruning levels and fertigation schedules for guava, and also to understand crop regulation and fertigation in guava (Psidium guajava L.) cv. Sarader for growth, physiology, yield and quality.

The treatment includes three levels of pruning ( $\mathrm{P}_{0}$ without pruning, $\mathrm{P}_{1^{-}}-15 \mathrm{~cm}$ pruning, $\mathrm{P}_{2^{-}} 30$ $\mathrm{cm}$ pruning) and five levels of fertigation $\left(\mathrm{F}_{0}\right.$ - Soil application of RDF(1000: 1000: $1000 \mathrm{~g}$ NPK plant ${ }^{-1}$ year $\left.^{-1}\right), F_{1}$ - Drip fertigation of $125 \%$ RDF (1250: 1250: 1250 g NPK plant $^{-1}$ year $\left.^{-1}\right), \mathrm{F}_{2}$ - Drip fertigation of $100 \% \mathrm{RDF}$ (1000: 1000: $1000 \mathrm{~g} \mathrm{NPK}$ plant $^{-1}$ year $^{-1}$ ), $\mathrm{F}_{3^{-}}$ Drip fertigation of $75 \%$ RDF (750: 750: 750 g NPK plant ${ }^{-1}$ year $\left.^{-1}\right), \mathrm{F}_{4}$ - Drip fertigation of $50 \%$ of RDF (500: 500: 500 g NPK plant ${ }^{-1}$ year $\left.^{-1}\right)$, with three replication.

The soil application with drip irrigation was done in two split doses during June-July and October-November. Water Soluble Fertilizers (WSF) namely Urea, Polyfeed and White Potash were injected at weekly intervals in equal splits (52 weeks).

\section{Results and Discussion}

\section{Effect of crop regulation and fertigation on quality attributes}

The data presented in the Table 1 recorded that there was enhancement in fruit quality with the increasing in pruning and fertigation. The trees subjected to three levels of pruning and five levels of fertigation.

The parameters namely total soluble solids, ascorbic acid, total sugar (\%), reducing sugars (\%) were found to be higher, while the parameter titratable acidity was low in the first year and second year.

The maximum TSS was recorded in the treatment combination of $\mathrm{P}_{2} \mathrm{~F}_{1}$ and the minimum recorded in the treatment combination control $\mathrm{P}_{0} \mathrm{~F}_{0}$. 
Table.1 Effect of crop regulation and fertigation on quality characters of guava (Psidium guajava) cv. Sardar

\begin{tabular}{|c|c|c|c|c|c|c|c|c|c|c|}
\hline & \multicolumn{2}{|c|}{ TSS ( ${ }^{0}$ Brix) } & \multicolumn{2}{|c|}{ TitrableAcidity (\%) } & \multicolumn{2}{|c|}{$\begin{array}{l}\text { Ascorbic acid } \\
\text { (mg/100g pulp) }\end{array}$} & \multicolumn{2}{|c|}{ Total Sugar (\%) } & \multicolumn{2}{|c|}{ Reducing Sugar (\%) } \\
\hline & Rainy & Winter & Rainy & Winter & Rainy & Winter & Rainy & Winter & Rainy & Winter \\
\hline $\mathbf{P}_{\mathbf{0}} \mathbf{F}_{\mathbf{0}}$ & 9.88 & 10.02 & 0.72 & 0.62 & 163.04 & 158.71 & 6.08 & 7.12 & 3.56 & 4.20 \\
\hline $\mathbf{P}_{0} \mathbf{F}_{1}$ & 10.67 & 10.62 & 0.64 & 0.49 & 190.51 & 195.33 & 7.31 & 7.64 & 4.23 & 4.47 \\
\hline $\mathbf{P}_{0} \mathbf{F}_{2}$ & 10.59 & 10.53 & 0.66 & 0.50 & 188.97 & 190.57 & 7.15 & 7.57 & 4.14 & 4.42 \\
\hline $\mathbf{P}_{\mathbf{0}} \mathbf{F}_{3}$ & 10.43 & 10.41 & 0.67 & 0.52 & 185.82 & 184.21 & 6.97 & 7.51 & 4.01 & 4.40 \\
\hline $\mathbf{P}_{0} \mathbf{F}_{4}$ & 10.34 & 10.33 & 0.68 & 0.55 & 181.59 & 180.29 & 6.72 & 7.46 & 3.94 & 4.37 \\
\hline $\mathbf{P}_{1} \mathbf{F}_{0}$ & 10.15 & 10.14 & 0.70 & 0.58 & 170.77 & 170.63 & 6.35 & 7.24 & 3.69 & 4.27 \\
\hline $\mathbf{P}_{1} \mathbf{F}_{1}$ & 11.15 & 11.13 & 0.58 & 0.45 & 203.93 & 212.55 & 7.91 & 8.19 & 4.60 & 4.69 \\
\hline $\mathbf{P}_{\mathbf{1}} \mathbf{F}_{2}$ & 11.04 & 10.99 & 0.58 & 0.46 & 200.16 & 212.18 & 7.78 & 8.04 & 4.52 & 4.63 \\
\hline $\mathbf{P}_{\mathbf{1}} \mathbf{F}_{\mathbf{3}}$ & 10.94 & 10.83 & 0.60 & 0.47 & 196.93 & 207.29 & 7.61 & 7.78 & 4.43 & 4.53 \\
\hline $\mathbf{P}_{1} \mathbf{F}_{\mathbf{4}}$ & 10.79 & 10.75 & 0.62 & 0.48 & 194.35 & 201.69 & 7.52 & 7.71 & 4.39 & 4.50 \\
\hline $\mathbf{P}_{2} \mathbf{F}_{0}$ & 10.23 & 10.25 & 0.69 & 0.58 & 176.93 & 174.84 & 6.53 & 7.41 & 3.81 & 4.34 \\
\hline $\mathbf{P}_{2} \mathbf{F}_{1}$ & 11.78 & 12.09 & 0.44 & 0.37 & 220.75 & 232.96 & 8.64 & 8.89 & 4.89 & 4.92 \\
\hline $\mathbf{P}_{\mathbf{2}} \mathbf{F}_{2}$ & 11.51 & 11.78 & 0.47 & 0.40 & 214.61 & 226.38 & 8.55 & 8.56 & 4.86 & 4.81 \\
\hline $\mathbf{P}_{2} \mathbf{F}_{3}$ & 11.33 & 11.56 & 0.50 & 0.42 & 211.88 & 220.49 & 8.24 & 8.51 & 4.79 & 4.79 \\
\hline $\mathbf{P}_{2} \mathbf{F}_{4}$ & 11.21 & 11.25 & 0.53 & 0.44 & 208.39 & 214.70 & 8.11 & 8.35 & 4.73 & 4.72 \\
\hline SEd & 0.22 & 0.22 & 0.013 & 0.013 & 3.87 & 2.98 & 0.13 & 0.15 & 0.05 & 0.06 \\
\hline $\mathrm{CD}(0.05)$ & 0.43 & 0.49 & 0.027 & 0.026 & 7.75 & 5.96 & 0.26 & 0.31 & 0.10 & 0.13 \\
\hline
\end{tabular}

Pruning $\left(\mathrm{P}_{0}\right.$ Without pruning, $\mathrm{P}_{1}-15 \mathrm{~cm}$ pruning, $\mathrm{P}_{2^{-}} 30 \mathrm{~cm}$ pruning)

Fertigation ( $\mathrm{F}_{0}-$ Soil application of RDF (1000: 1000: $1000 \mathrm{~g} \mathrm{NPK}$ plant $^{-1}$ year $^{-1}$ )

$\mathrm{F}_{1}$-Drip fertigation of $125 \% \mathrm{RDF}$ (1250: 1250: $1250 \mathrm{~g} \mathrm{NPK}$ plant $^{-1} \mathrm{year}^{-1}$ )

$\mathrm{F}_{2}$ - Drip fertigation of $100 \%$ RDF (1000: 1000: $1000 \mathrm{~g} \mathrm{NPK}$ plant $^{-1}$ year $^{-1}$ )

$\mathrm{F}_{3^{-}}$Drip fertigationof $75 \% \mathrm{RDF}$ (750: 750: $750 \mathrm{~g} \mathrm{NPK}_{\text {plant }}{ }^{-1}$ year $^{-1}$ )

$\mathrm{F}_{4}$ - Drip fertigation of $50 \%$ of RDF (500: 500: $500 \mathrm{~g} \mathrm{NPK}$ plant $^{-1}$ year $^{-1}$ ) 
The maximum ascorbic acid in the treatment combination in the $\mathrm{P}_{2} \mathrm{~F}_{1}$ and the minimum Ascorbic acid recorded in the treatment combination $\mathrm{P}_{0} \mathrm{~F}_{0}$. The maximum Total sugar (\%) in the treatment combination in the $\mathrm{P}_{2} \mathrm{~F}_{1}$ and the minimumTotal sugar $(\%)$ recorded in the treatment combination $\mathrm{P}_{0} \mathrm{~F}_{0}$. The maximum Reducing sugars (\%) in the treatment combination in the $\mathrm{P}_{2} \mathrm{~F}_{1}$ and the minimumReducing sugars $(\%)$ recorded in the treatment combination control $\mathrm{P}_{0} \mathrm{~F}_{0}$. The lowest Titratable acidityin the treatment combination in the $\mathrm{P}_{2} \mathrm{~F}_{1}$ and the maximum Titratable acidity recorded in the treatment combination control $\mathrm{P}_{0} \mathrm{~F}_{0}$.

In case in total soluble solids, ascorbic acid, total sugar $(\%)$, reducing sugars $(\%)$ were found to be higher, titratable acidity regularly pruning and fertigation might be due to the due to the prevalence of low temperature receives at the time of fruit ripening, which not only retarded the excessive loss of respiratory substances but also increased the translocation of photosynthates from leaves to the fruits (Singh and Dhaliwal, 2004). The maximum fruit quality might be due to increased accumulation of metabolites and rendered better fruit quality of winter crop due to diversion of synthesized food materials of spring flushed crop to monsoon flushed crop (Chandra and Govind, 1995). The increase titrable acidity in the control treatments is due to lower rate of reduction of starch to sugars, competition and light unavailability (Lal, 1992; Mishra, 2000).

Among various fertigation levels, higher doses showed better qualities of the plant. It might be due to application of higher dose of fertilizers attributed to better nutritional environment in the root zone as well as in plant system. Nitrogen, phosphorus and potassium are most indispensable of all mineral nutrients for growth and development of the plant as these are the basis of fundamental constituents of all living matter
(Throughton et al., 1974). The highest fruit quality is might be due to nitrogen stimulates the functioning of enzymes in the physiological processes, which have improved the total soluble solids content of the fruits. The highest total sugar was attributed to the involvement of nitrogen in various energy sources like amino acids and amino sugars (Dutta et al., 2010). The maximum total soluble solids, ascorbic acid, reducing sugars, non-reducing sugars, total sugars and pectin content by application of NPK may be explained by the fact that phosphorus enters into the composition of phospholipids and nucleic acid, the latter combination with proteins and results in the formation of nucleo - proteins which are important constituents of the nuclei of the cell. Potassium acts as a catalyst in the formation of more complex substances and in the acceleration of enzyme activity. These carbohydrates and coenzymes are beneficial in the improvement of fruits quality and nitrogen enhances the uptake of phosphorus and potassium due to the chain reaction in these components might have possibly caused important in quality of fruits (Kumar et al., 2009).

There was enhancement in quality characters with the increasing in pruning and fertigation the maximum total soluble solids, ascorbic acid, total sugar $(\%)$, reducing sugars $(\%)$, lowest titratable recorded in the $\mathrm{P}_{2}$ and fertigation $\mathrm{F}_{2}$.

The investigation of pruning and fertigation is increases total soluble solids, ascorbic acid, total sugar $(\%)$, reducing sugars (\%) recorded in the $\mathrm{P}_{2} \mathrm{~F}_{1}$ treatments.

\section{References}

Agrawal N, Agrawal S. 2007. Effect of different levels of drip irrigation on the growth and yield of pomegranate under Chhattisgarh Region. Orissa. J. Hort.35:38-46. 
Aravindakshan, M. 1953. Effect of pruning on growth, flowering and fruit set of guava (Psidium guajava L.). Madras Agric. J., 51: 87-90.

Bajpai, P.N., Shukla, H.S. and Chaturvedi,.M.1973.Effect of pruning on growth, yield and quality of guava (Psidium guajava L.) var. Allahabad Sufeda. Prog. Hort., 5: 73-79.

Ball, J.S. and Dhaliwal, G.S. 2003. Height density planting studies in guava. Haryana J.Hort.Sci., 32(1\&2): 19-20.

Bharambe PR, Mungal MS, Shelke DK, Oza SR, Vaishnava VG, and SondgeVD.2001. Effect of soil moisture regimes with drip on spatial distribution of moisture, salts, nutrient availability and water use efficiency of banana. J. Ind. Soc. Soil Sci. 49:658-665.

Chandra, R. and Govind, S. 1995. Influence of time and intensity of pruning on growth, yield and fruit quality of guava under high density planting. Tropical Agric. 72: 11013.

Dasarathy, T.B. 1951. The guava. Madras Agric. J., 38: 520-526.

Dutta, P., Kundu, S. and Biswas, S. 2010. Nutrient management in litchi in new alluvial zone of West Bengal. Indian J. Hort. 67:181-84.

Gill, H.S. 1994. Pruning studies on Sardar guava. M.Sc. Thesis, Punjab Agricultural University, Ludhiana, Punjab (India).

Gurdarshan Singh. 2012. Influence of pruning intensity and pruning frequency on vegetative and reproductive attributes of sardar guava. The Asian J.Horti.7(1) 108112.

Jadho, B.J., Dmke, M.M., Mhorkar, V.K., Dod, V.N. and Wgh, A.P. 1988. Studies on effect of time and severity of pruning on growth and yield of guava (Psidium guajava L.) cv. SARADER. J. Soils Crops, 8 (2): 139-141.

Kumar A, Singh R.K, Sinha A.K, Singh H.K, and Mishra, A.P. 2007.Effect of fertigation on banana through drip irrigation in North Bihar. J. Res. Birsa Agric. Univ. 19:81-86.

Kumar Pankaj, Tiwari, J. P. and Raj Kumar. 2008. Effect of NP\&K on fruiting and yield and quality in guava cv. Pant Prabhat. J.Hort.Sci., 3(1):43-47.

Lal and Sen, N.L. 2001. Effect of N, Zn and Mn fertilization on fruit quality of guava cv. Allahabad Safeda. Haryana J.Hort.Sci., 30 (3/4):209-210.

Medeiros, B.G. 2004. Physical characteristics of guava: effect of the manuring with nitrogen. Revista Brasileria de Productos Agroindustriais, 6 (1): 47-53.

Mishra, D.S. 2000. Effect of plant density on performance of guava (Psidium guajava L.) Thesis, Doctor of Philosophy (Horticulture).G.B. Pant University of Agricultural and Technology, Pantnagar. U.S.NAGAR. UTTARAKHAND (India).

Salvin S, Baruah, K. and Bordoloi, S.K. 2000. Drip irrigation studies in banana $\mathrm{cv}$. Barjahaji (Musa AAA group, Cavendish sub-group). Crop Res. 20:489-493.

Sharma S, Patra, S.K, Ray, R. 2011. Effect of drip fertigation on growth and yield of guava cv. Khaja. Environ. Eco.29:34-38.

Singh, Ajitpal and Dhaliwal, G.S. 2004. Influence of radiation interception and canopy temperature on fruit quality of Sardar guava at different planting distance. Indian $J$. Hort. 61: 118-21.

Throughton JH, Morrby J, and Currie, B.G. 1974. Investigation of carbon transport in plants. J. Exp. Bot. 25:684-694.

\section{How to cite this article:}

Mahadevan, A., S. Kumar, V. Swaminathan, A. Gurusamy and Sivakumar, T. 2017. Effect of Crop Regulation and Fertigation on Quality Characters of Guava (Psidium guajava) CV. Sardar. Int.J.Curr.Microbiol.App.Sci. 6(11): 2137-2141. doi: https://doi.org/10.20546/ijcmas.2017.611.251 